\title{
Influence of Palmitate and Oleate on the Binding of Warfarin to Human Serum Albumin: Stopped-Flow Studies
}

\author{
By N. Rietbrock, G. Menke, G. Reuter, A. Laßmann and R. Schmeidl \\ Abteilung für Klinische Pharmakologie am Klinikum der Johann Wolfgang Goethe-Universität Frankfurt
}

(Received August 31, 1984/April 30/August 5, 1985)

\begin{abstract}
Summary: The rate of transition from an unstable to a stable complex and the dependence of this on the number of fatty acid ligands present was determined for the binding of warfarin on human serum albumin. When oleate or palmitate was added in amounts up to 2:1 excess to human serum albumin solutions the measured rate constant for the transition $\left(\mathrm{k}_{2}\right)$ was increased in comparison with fatty acid free albumin. When the fatty acid concentration is further increased, $k_{2}$ decreases. When the fatty acid level is 2 to 3 mol per mol albumin, the affinity constant $\left(\mathrm{K}_{\mathrm{A}}\right)$ is higher than for fatty acid free solutions. With higher ratios the value for $\mathrm{K}_{\mathrm{A}}$ is reduced.

According to the observed changes in kinetic parameters, the binding of warfarin is apparently affected allosterically. A reduced plasma protein binding of coumarins should be expected when fatty acid levels are raised over a prolonged period.
\end{abstract}

\section{Einflu $\beta$ von Palmitat und Oleat auf die Bindung von Warfarin an menschliches Serumalbumin: Stopped-Flow Untersuchungen}

Zusammenfassung: Bei der Bindung von Warfarin an Humanserumalbumin wird die Geschwindigkeit der Umlagerung vom instabilen in den stabilen Warfarin-Humanserumalbuminkomplex von der Anzahl der Fettsäureliganden bestimmt. Wird Oleat oder Palmitat zu einer Lösung von Humanserumalbumin gegeben, werden bis zum Überschuß von 2:1 höhere Werte für die Geschwindigkeitskonstante der Umlagerung $\left(\mathrm{k}_{2}\right)$ als bei fettsäurefreiem Humanserumalbumin gemessen. Bei weiterer Erhöhung der Fettsäurekonzentration nimmt $\mathbf{k}_{2}$ ab. Auch die Bindungskonstante $\left(\mathrm{K}_{\mathrm{A}}\right)$ ist abhängig vom Grad der Komplexierung des Humanserumalbumins mit den freien Fettsäuren. Bei 2 bis 3 mol Fettsäure pro mol Albumin werden höhere Affinitätskonstanten gefunden als in fettsäurefreien Albuminlösungen; bei einem höherem Verhältnis sind die Werte für $\mathrm{K}_{\mathrm{A}}$ erniedrigt.

Entsprechend den Änderungen der kinetischen Kenngrößen wird die Warfarinbindung offensichtlich allosterisch beeinflußt. Bei längerfristig erhöhter Fettsäurekonzentration im menschlichen Plasma ist daher eine verminderte Eiweißbindung für Cumarịne anzunehmen.

\section{Introduction}

Human serum albumin has several binding sites for endogenous and exogenous substances. The warfarin binding site $(1-5)$ and the indole or benzodiazepine binding site $(2,4-8)$ interact specifically with these ligands. Other specific binding sites for bilirubin (9, $10)$, digitoxin $(4,11-14)$ and for long-chain fatty acids $(15-20)$ have been suggested. According to the binding studies by Goodman (21) two molecules of free fatty acid undergo specific binding, whereas further molecules associate unspecifically. Although the warfarin binding site is located separately, the warfarin binding process is dependent on the degree of saturation of the albumin molecule by free fatty acids $(16,22)$. Thus, a study of the kinetics of the warfarinalbumin binding process should provide information on interaction mechanisms - whether competitive or allosteric - between these two different classes of binding sites on albumin. 


\section{Materials and Methods}

A solution of fatty acid-free human albumin was prepared by dissolving crystalline albumin (Sigma, St. Louis, USA) in double distilled water. The fatty acid content of this solution using the method of Duncombe (23) was 0.03 mol per mol albumin. The concentration of albumin was determined by UVspectroscopy using the absorbance value $A_{280 \mathrm{~nm}}^{1}=5.3$ for solutions of $10 \mathrm{~g} / \mathrm{l}$ albumin in water at $\mathrm{pH}=7.4$ and $\mathrm{T}=298 \mathrm{~K}$. Solutions used for the measurements were obtained by dilution with $0.066 \mathrm{~mol} / \mathrm{l}$ Sörensen phosphate buffer.

Concentration of warfarin (3-acetonylbenzyl-4-hydroxycoumarin) dissolved in Sörensen buffer was determined photometrically using the molar lineic absorbance $\varepsilon_{310 \mathrm{~mm}}=1.76$. $10^{3} \mathrm{~m}^{2} / \mathrm{mol}$.

Solid sodium palmitate and sodium oleate (Sigma) were dissolved in albumin solutions by stirring and the concentration determined using the method of Duncombe (23).

Kinetics of warfarin binding were studied in a Durrum-Gibson stopped-flow apparatus $(22,24)$. The complexation reaction was followed from the time course of fluorescence development. Excitation energy was generated by a Xenon-high-pressure lamp (150 Watt) with a maximum at $380 \mathrm{~nm}$. Emission radiation was monitored at $324 \mathrm{~nm}$ with sharp cut filtering for scattered light of wavelength greater than $360 \mathrm{~nm}$. Fluorescence signals were displayed on an oscillograph and stored on floppy discs.

The calculation of kinetic parameters was carried out as described by Rietbrock \& Laßmann (24). Two coupled equilibria are involved in the binding reaction (I):

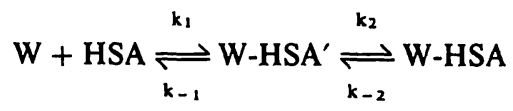

Association into the primary, unstable complex W-HSA' is fast and goes to completion in less than $3 \mathrm{~ms}$, which is within the dead time of the instrument. Kinetics of this process are thus too rapid to be studied by stopped-flow measurement. Rearrangement into the final stable complex, W-HSA, lasts several hundred milliseconds and is the rate-limiting step. The overall velocity can be characterized by the relaxation constant $\mathbf{k}_{\text {rel }}$ (25):

$$
k_{\mathrm{rel}}=\mathrm{k}_{2} \frac{\mathrm{K}_{\mathrm{A}}^{\prime}\left(\mathrm{c}_{\overline{\mathrm{w}}}+\mathrm{c}_{\overline{\mathrm{HSA}}}\right)}{1+\mathrm{K}_{\mathrm{A}}^{\prime}\left(\mathrm{c}_{\overline{\mathrm{W}}}+\mathrm{c}_{\mathrm{HSA}}\right)}+k_{-2}
$$

Rearrangement leads to a linear relationship between experimental and calculated constants:

$$
\frac{1}{\mathrm{k}_{\mathrm{rel}}-\mathrm{k}_{-2}}=\frac{1}{\mathrm{k}_{2}}+\frac{1}{\mathrm{k}_{2} \cdot \mathrm{K}_{\mathrm{A}}^{\prime}\left(\mathrm{c}_{\overline{\mathrm{W}}}+\mathrm{c}_{\overline{\mathrm{HSA}}}\right)}
$$

$\mathbf{K}_{\mathbf{A}}^{\prime}$ is the affinity constant of the primary complex, $c_{\bar{W}}$ and $c_{\mathrm{HSA}}$ are concentrations of free warfarin and albumin at equilibrium. The binding or affinity constant $\mathrm{K}_{\mathrm{A}}$ for the overall binding process is obtained by:

$$
\mathrm{K}_{\mathrm{A}}=\mathrm{K}_{\mathrm{A}}^{\prime} \frac{\mathrm{k}_{2}}{\mathrm{k}_{-2}}
$$

\section{Results}

Effect of variable palmitate concentrations on the kinetics of warfarin binding on human serum albumin

The influence of sodium palmitate on the rate of warfarin complexation was studied using a human serum albumin concentration in the range $0.03 \cdot 10^{-4}$ $\mathrm{mol} / \mathrm{l}$ to $1.09 \cdot 10^{-4} \mathrm{~mol} / \mathrm{l}$ and a warfarin concentration of $0.025 \cdot 10^{-4} \mathrm{~mol} / \mathrm{l}$ or $0.05 \cdot 10^{-4} \mathrm{~mol} / \mathrm{l}$. Typical fluorescence signals are shown in figure 1 , and $k_{r e l}$ values, obtained by iterative calculation, are listed in table $1 \mathrm{a}$. Velocity constants $\mathbf{k}_{2}$ (associative process) and $k_{-2}$ (dissociative process) combined with affinity constants $\mathrm{K}_{\mathrm{A}}^{\prime}$ and $\mathrm{K}_{\mathrm{A}}$ (tab. $2 \mathrm{a}$ ) show evidence for a relationship between warfarin binding on albumin and free fatty acid ligandation. Binding velocity is enhanced by raising the molar concentration ratio to 2 mol palmitate per mol albumin. Relaxation constants therefore increase, but on raising the concentration further to more than $3 \mathrm{~mol}$ palmitate per mol albumin, they decrease. The velocity constant $k_{2}$ is maximal in the presence of $2 \mathrm{~mol}$ free fatty acid per mol albumin with $\mathrm{k}_{2}=171.6 \mathrm{~s}^{-1}$ in comparison with $76.9 \mathrm{~s}^{-1}$ for fatty acid-free albumin. With $5 \mathrm{~mol}$ palmitate per mol albumin $\mathrm{k}_{2}$ is $56.0 \mathrm{~s}^{-1}$ (tab. 2a). $\mathrm{k}_{-2}$, on the other hand, is independent of the degree of fatty acid ligandation and is approximately $20 \mathrm{~s}^{-1}$ (fig. 2). As a consequence of these findings the binding constant $\mathrm{K}_{\mathrm{A}}, 3.6 \cdot 10^{5} \mathrm{l} / \mathrm{mol}$ (see equation IV), is affected in a similar manner as $k_{2}$ and shows a maximum when three mol palmitate are present.

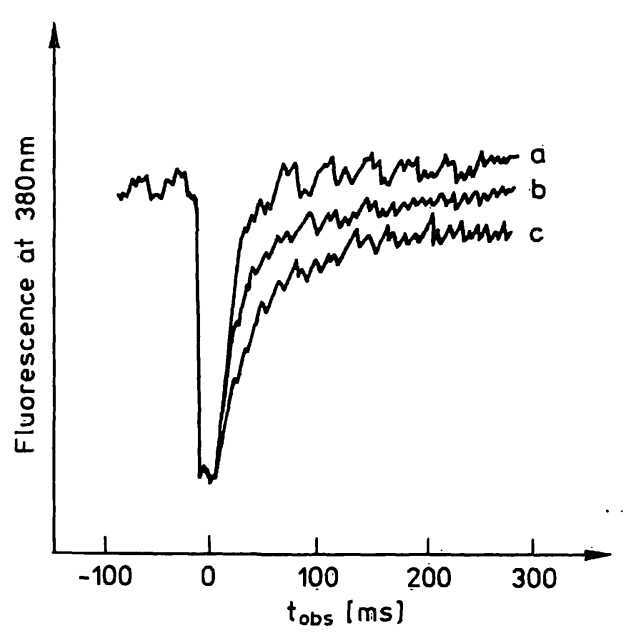

Fig. 1. The time course of the fluorescence development $(380$ $\mathrm{nm}$ ) of warfarin during complex formation with human serum albumin at $310 \mathrm{~K}$ and $\mathrm{pH}=7.4$ using excitation at $324 \mathrm{~nm}$. The concentrations of reactants were: $c_{\mathrm{HSA}}=$ $2 \cdot 10^{-5} \mathrm{~mol} / \mathrm{l}, \mathrm{c}_{\mathrm{W}}=5 \cdot 10^{-6} \mathrm{~mol} / \mathrm{l}$. $\mathrm{t}_{1 / 2}$ for palmitate/ human serum albumin molar ratios of (a) 1 , (b) 2.5 and (c) 4 were $10 \mathrm{~ms}, 19 \mathrm{~ms}$ and $29 \mathrm{~ms}$, respectively. 
Tab. 1. (a) Effect of the molar ratio of palmitate to human serum albumin (PA/HSA) on the relaxation constant $\mathbf{k}_{\mathrm{rel}}$ for the binding of warfarin (W) to human serum albumin at $\mathrm{T}=310 \mathrm{~K}$ and $\mathrm{pH}=7.4$.

(b) Effect of the molar ratio of oleate to human serum albumin (OL/HSA) on the relaxation constant $k_{\text {rel }}$ for the binding of warfarin (W) to human serum albumin Tab. 1a. at $\mathrm{T}=310 \mathrm{~K}$ and $\mathrm{pH}=7.4$.

\begin{tabular}{lllllll}
\hline \multicolumn{7}{c}{ PA/HSA } \\
$c_{\text {HSA }}$ & \multicolumn{7}{c}{$c_{W}$} & $0: 1$ & $1: 1$ & $2: 1$ & $3: 1$ & $5: 1$ \\
$\left(10^{-4} \mathrm{~mol} / 1\right)$ & & & $\mathrm{k}_{\text {rel }}\left(\mathrm{s}^{-1}\right)$ & & & \\
\hline 0.028 & 0.025 & 27 & 31 & - & - & - \\
0.055 & 0.025 & 28 & 39 & 34 & 46 & 21 \\
0.092 & 0.025 & 32 & 52 & 39 & 48 & 32 \\
0.135 & 0.025 & 36 & 57 & 57 & 63 & 40 \\
0.270 & 0.025 & 45 & 75 & 79 & 75 & 47 \\
0.540 & 0.050 & 57 & 87 & 113 & 116 & 42 \\
1.087 & 0.050 & 58 & 90 & 101 & 127 & 50 \\
\hline
\end{tabular}

Tab. 1b.

\begin{tabular}{|c|c|c|c|c|c|c|c|}
\hline \multirow{2}{*}{\multicolumn{2}{|c|}{$\begin{array}{l}\mathrm{C}_{\mathrm{HS \Lambda}} \mathrm{C}_{\mathrm{W}} \\
\left(10^{-4} \mathrm{~mol} / \mathrm{l}\right)\end{array}$}} & \multicolumn{2}{|c|}{ OL/HSA } & \multirow[b]{2}{*}{$2: 1$} & \multirow[b]{2}{*}{$3: 1$} & \multirow[b]{2}{*}{$4: 1$} & \multirow[b]{2}{*}{$6: 1$} \\
\hline & & \multicolumn{2}{|c|}{$k_{\mathrm{rel}}\left(s^{-1}\right)$} & & & & \\
\hline 0.028 & 0.025 & 27 & 87 & 81 & 99 & 71 & 76 \\
\hline 0.055 & 0.025 & 28 & 88 & 90 & 87 & 78 & 67 \\
\hline 0.092 & 0.025 & 32 & 101 & 105 & 86 & 87 & 68 \\
\hline 0.135 & 0.025 & 36 & 108 & 115 & 112 & 81 & 87 \\
\hline 0.270 & 0.025 & 45 & 129 & 159 & 127 & 94 & 93 \\
\hline
\end{tabular}

Tab. 2. The rate constants $\left(k_{2}, k_{-2}\right)$ and affinity constants $\left(\mathrm{K}_{\mathrm{A}}^{\prime}, \mathrm{K}_{\mathrm{A}}\right)$ for the association and dissociation of warfarin to human serum albumin at $310 \mathrm{~K}$ and $\mathrm{pH}=7.4$ as a function of:

(a) palmitate concentration;

(b) oleate concentration.

Tab. 2a.

\begin{tabular}{|c|c|c|c|c|c|}
\hline \multirow[t]{2}{*}{ Parameter } & \multicolumn{2}{|c|}{ PA/HSA } & \multirow[b]{2}{*}{$2: 1$} & \multirow[b]{2}{*}{$3: 1$} & \multirow[b]{2}{*}{$5: 1$} \\
\hline & $0: 1$ & 1:1 & & & \\
\hline $\begin{array}{l}\mathbf{K}_{\mathbf{A}}^{\prime} \cdot 10^{-4}(1 / \mathrm{mol}) \\
\mathbf{k}_{2}\left(\mathbf{s}^{-1}\right) \\
\mathbf{K}_{2} \cdot \mathbf{K}_{\mathbf{A}}^{\prime} \cdot 10^{-5}(1 / \mathrm{mol} \cdot \mathrm{s}) \\
\mathbf{K}_{-2}\left(\mathbf{s}^{-1}\right) \\
\mathbf{K}_{\mathbf{A}} \cdot 10^{-5}(1 / \mathrm{mol})\end{array}$ & $\begin{array}{r}3.1 \\
76.9 \\
24.0 \\
18.0 \\
1.3\end{array}$ & $\begin{array}{r}3.3 \\
119.0 \\
39.2 \\
21.0 \\
1.8\end{array}$ & $\begin{array}{r}3.8 \\
171.6 \\
31.5 \\
20.0 \\
1.6\end{array}$ & $\begin{array}{r}3.5 \\
144.3 \\
49.9 \\
14.0 \\
3.6\end{array}$ & $\begin{array}{r}5.4 \\
56.0 \\
30.4 \\
10.0 \\
3.1\end{array}$ \\
\hline
\end{tabular}

Tab. 2 b.

\begin{tabular}{lrrrrrr}
\hline Parameter & \multicolumn{1}{c}{ OL/HSA } & & & & \\
& $0: 1$ & $1: 1$ & $2: 1$ & \multicolumn{1}{c}{$3: 1$} & \multicolumn{1}{c}{$4: 1$} & $6: 1$ \\
\hline $\mathrm{K}_{\mathrm{A}}^{\prime} \cdot 10^{-4}(\mathrm{l} / \mathrm{mol})$ & 3.1 & 5.0 & 4.8 & 12.9 & 20.2 & 4.5 \\
$\mathrm{~K}_{2}\left(\mathrm{~s}^{-1}\right)$ & 76.9 & 111.3 & 176.2 & 112.4 & 67.3 & 80.2 \\
$\mathrm{~K}_{2} \cdot \mathrm{K}_{\mathrm{A}}^{\prime} \cdot 10^{-5}(\mathrm{l} / \mathrm{mol} \cdot \mathrm{s})$ & 24.0 & 55.7 & 84.6 & 145.0 & $135: 9$ & 36.1 \\
$\mathrm{~K}_{-2}\left(\mathrm{~s}^{-1}\right)$ & 18.0 & 66.0 & 50.0 & 44.0 & 43.0 & 49.0 \\
$\mathrm{~K}_{\mathrm{A}} \cdot 10^{-5}(\mathrm{l} / \mathrm{mol})$ & 1.3 & 0.8 & 1.7 & 3.3 & 3.2 & 0.7 \\
\hline
\end{tabular}

Effect of variable oleate concentrations on the kinetics of warfarin binding on human serum albumin

The influence of bound oleate on the binding kinetics of warfarin was examined using the same methods as described previously for palmitate. Albumin concentration was varied from $0.03 \cdot 10^{-4} \mathrm{~mol} / 1$ to 0.27 $\cdot 10^{-4} \mathrm{~mol} / \mathrm{l}$ and the warfarin concentration was held constant at $0.025 \cdot 10^{-4} \mathrm{~mol} / \mathrm{l}$. As with palmitate, there was a significant relationship between the oleate concentration and the relaxation constant (tab. $1 \mathrm{~b}$ ). $\mathrm{k}_{2}$ was maximal, $176.2 \mathrm{~s}^{-1}$, in the presence of $2 \mathrm{~mol}$ oleate per mol albumin. The velocity constant $k_{-2}$, as before, is relatively constant and a maximal binding constant occurs with $3 \mathrm{~mol}$ oleate per mol albumin (tab. 2 b). With progressively higher oleate concentrations warfarin binding is inhibited to a limited extent, as shown by the relationships between $k_{2}, k_{-2}$ and the molar ratio (fig. 2).

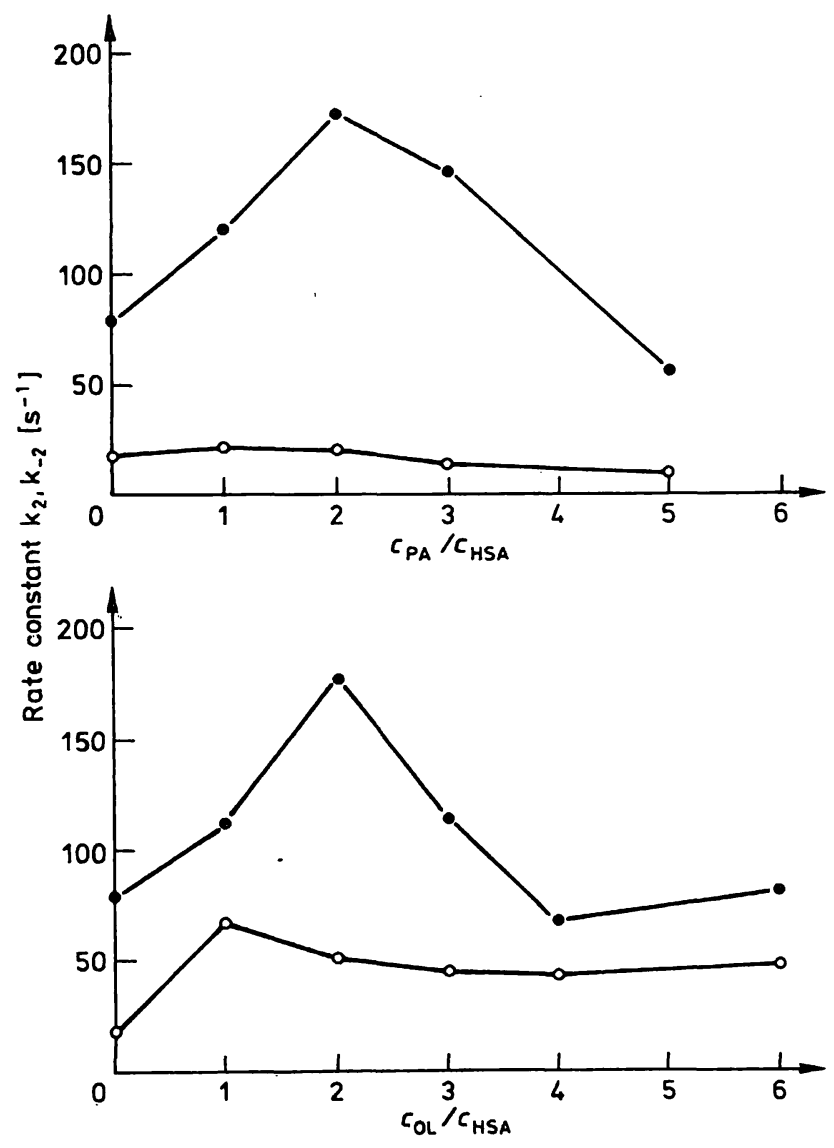

Fig. 2. The dependency of the rate constant $k_{2}(0-0)$ and $k_{-2}$ $(0-0)$, measured at $310 \mathrm{~K}$ and $\mathrm{pH}=7.4$ on the fatty acid concentration shown as molar ratios: $c_{P A} / c_{H S A}$ for palmitate $\left(c_{\mathrm{PA}}\right)$, and $\mathrm{c}_{\mathrm{OL}} / \mathrm{c}_{\mathrm{HSA}}$ for oleate $\left(\mathrm{c}_{\mathrm{OL}}\right)$. 


\section{Discussion}

The kinetics of the specific warfarin human serum albumin binding process is clearly dependent on the concentration of free fatty acids. The enhancement of the warfarin interactions at its specific binding site is evidently caused by an allosteric effect since the binding sites for the two ligands seem to be located apart from one another. The rate of rearrangement, described by the velocity constant $k_{2}$, is increased when 2 to $3 \mathrm{~mol}$ free fatty acid per mol albumin occupy their binding sites. According to the kinetic parameters the rearrangement from the primary unstable complex W-HSA' into the stable complex WHSA appears to be the rate limiting step (tab. $2 \mathrm{a}$ and 2 b). Presumably warfarin, in its deprotonated form, is bound to several amino-acid side chains in the active cleft. Conformational changes in albumin to produce the stable bound state are facilitated when the 2 specific fatty acid binding sites are occupied. This is reflected in the binding constant $\mathrm{K}_{\mathrm{A}}$, and a competitive interaction between the different ligands can be excluded.

The results obtained for saturated and unsaturated fatty acids were similar and thus side-chain stereochemistry is not a determinant factor in this phenomenon. The affinity constants derived from the kinetic parameters agree well with data of Wilding et al. (16) measured directly using equilibrium dialysis. These authors obtained maximal values for $\mathrm{K}_{\mathrm{A}}$ when the oleate or palmitate to albumin molar ratio was 3 . The extent of this agreement would of course be dependent on the assumption that the reaction model on which calculation of kinetic parameters was based faithfully reflects the events of the binding and interaction process. The effects of fatty acids on the rate constant $\mathrm{k}_{2}$, which are maximal at a molar ratio of approximately 2 , is in accord with the known existence of 2 binding sites for free fatty acids on human serum albumin. In contrast, the binding constant $\mathrm{K}_{\mathrm{A}}$ is influenced to some extent by variations in $\mathrm{K}_{\mathrm{A}}^{\prime}$, the pre-equilibrium constant. In the results obtained for the unsaturated fatty acid oleate, but not palmitate, there also seems to be some relationship between oleate concentration and unspecific association (tab. 2 b). Here different solution properties based on side chain stereochemistry may come into question.

Apart from two specific binding sites, there are several unspecific binding locations which exist on albumin. Their number however is not exactly known. Warfarin and fatty acids are also bound simultaneously at unspecific sites. When these binding sites are saturated, competitive displacement or steric hinderance does occur and is reflected in the decrease in the extent of binding of warfarin on albumin in the presence of more than $5 \mathrm{~mol}$ fatty acid per mol albumin. Specific binding of other exogenous small ligands is inhibited.

Warfarin (Coumadin ${ }^{\circledR}$ ) was the chosen model ligand in this study to investigate binding properties as a function of the fatty acid level at binding site I. Structurally related coumarins include phenprocoumon (Marcumar ${ }^{\circledR}$ ) and acecoumarol (Sintron ${ }^{\circledR}$ ). Binding constants for these three drugs were of the same order (26) indicating that binding seems to be maintained essentially by the coumarin-ring. Thus, the conclusion from our investigation with warfarin may be extrapolated to phenprocoumon and acecoumarol.

A decrease or increase of coumarin protein binding could have an effect on the pharmacological activity of anticoagulant drugs. Short-term rises in fatty acid levels however do not influence the inhibition of blood clotting because of the long half-life time of clotting factors (27). On the other hand, diseases producing long-term increases in fatty acid levels, e. g. diabetes mellitus (28) and hyperthyreosis (29) or prolonged extended heparin therapy may cause an unwanted enhancement in drug action, in particular where hepatic coumarin-clearance remains constant.

\section{References}

1. Sudlow, G., Birkett, D. J. \& Wade, D. N. (1976) Mol. Pharmacol. 12, 1052-1061.

2. Müller, W. E. \& Wollert, U. (1979) Pharmacology 19, 59-67.

3. Fehske, K. J., Müller, W. E., Wollert, U. \& Velden, L. M. (1979) Mol. Pharmacol. 16, 778-189.

4. Sjöholm, I., Ekman, B., Kober, A., Ljungsted-Pahlman, I., Seiving, B. \& Sjödin, T. (1979) Mol. Pharmacol. 16, $767-777$.

5. Fehske, K. J., Müller, W. E. \& Wollert, U. (1979) Biochim. Biophys. Acta .557, 346-359.

6. Müller, W. E. \& Wollert, U. (1975) Naunyn-Schmiedeberg's Arch. Pharmacol. 228, 17-27.

7. Müller, W. E. \& Wollert, U. (1975) Res. Commun. Chem. Pathol. Pharmacol. 10, 565-568.

8. Gambhir, K. K., McMenamy, R. H. \& Watson, F. (1975) J. Biol. Chem. 250, 6711-6719.

9. Jacobson, J. (1969) FEBS Lett. 5, 112-114.

10. Reed, R. G. (1977) J. Biol. Chem. 252, 7483-7487.

11. Kober, A., Jenner, A., Sjöholm, I., Borga, O. \& OdarCederlöf, I. (1978) Biochem. Pharmacol. 27, 2729-2735.

12. Brock, A. (1976) Acta Pharmacol. Toxicol. 38, 497-507. 
13. Fehske, K. J. Jähnchen, E., Müller, W. E. \& Stillbauer, A. (1980) Naunyn-Schmiedeberg's Arch. Pharmacol. 313, $159-163$.

14. Lukis, D. S. \& DeMartino, A. G. (1969) J. Clin. Invest. 48, $1041-1045$.

15. Birkett, D. J., Myers, S. P. \& Sudlow, G. (1977) Mol. Pharmacol. 13, 987-995.

16. Wilding, G., Feldhoff, R. C. \& Vesell, E. S. (1977) Biochem. Pharmacol. 26, 1143-1146.

17. Chakrabarti, S. K. (1978) Biochem. Pharmacol. 27, $739-743$.

18. Odell, G. B. (1973) Ann. N. Y. Acad. Sci. 226, 225-237.

19. Hsia, J. C. (1978) Fed. Proc. 37, 1424.

20. Spector, A. A., Santos, E. C., Ashbrook, J. D. \& Fletcher, J. E. (1973) Ann. N. Y. Acad. Sci. 226, 247-258.

21. Goodman, D.W. (1958) J. Am. Chem. Soc. 80, 3892-3898.
22. Ulrich, R., Laßmann, A., Kaufmann, R. \& Rietbrock, N. (1983) Fresenius Z. Anal. Chem. 315, 534-538.

23. Duncombe, W. G. (1964) Clin. Chim. Acta 9, 122-125.

24. Rietbrock, N. \& Laßmann, A. (1980) Naunyn-Schmiedeberg's Arch. Pharmacol. 313, 269-274.

25. Bernasconi, C. F. (1976) Relaxation Kinetics, Academic Press, New York.

26. Bachmann, K. \& Shapiro, R. (1977) Clin. Pharmacokin. 2, 110-126.

27. Jähnchen, E. \& Trenk, D. (1981) In: Progress in Drug Protein Binding (Rietbrock, N., Woodcock, B. G. \& LaBmann, A., eds.) Vieweg Braunschweig, pp. 31-44.

28. Moorhouse, J. A., Steinberg, J. \& Rosen, N. J. (1963) J. Clin. Endocrin. Metabol. 23, 1080-1089.

29. Rich, C. E., Bierman, E. L. \& Schwartz, I. L. (1959) J. Clin. Invest. 38, 275-278.

Prof. Dr. med. N. Rietbrock

Abteilung für Klinische Pharmakologie am Klinikum

der Johann-Wolfgang-Goethe-Universität

Haus 74/IV

Theodor-Stern-Kai 7

D-6000 Frankfurt 70 
